\title{
Contribution of Learning Motivation and Learning Attitude to Student Learning Outcomes in Digital Simulation Courses
}

\author{
Mulya Melda', Hasan Maksum², Eko Indrawan'3 ${ }^{3}$ Dori Yuvenda ${ }^{4}$ \\ ${ }^{1}$ Jurusan Pendidikan Teknologi Kejuruan, Fakultas Teknik, Universitas Negeri \\ Padang \\ ${ }^{3}$ Jurusan Teknik Mesin, Fakultas Teknik, Universitas Negeri Padang \\ ${ }^{4}$ Jurusan Teknik Otomotif, Fakultas Teknik, Universitas Negeri Padang \\ mulyamelda08@gmail.com
}

$\begin{array}{ll}\text { Article History } & \text { Received : January } 2^{\text {th }} 2021 \\ & \text { Revision : February } 9^{\text {th }} 2021 \\ & \text { Publication : March 30th } 2021\end{array}$

\begin{abstract}
The background of this research is the low value of students in digital simulation courses of Informatics Engineering education and Computer Education FKIP UBH. Based on the data of the last three years, that the value of students under 70 reached $50 \%$. The purpose of this study is to find out how much contribution: (1) motivation to learn on student learning outcomes in digital simulation courses PTIK study program FKIP UBH Padang City, (2) attitude of learning to the results of learning in digital simulation courses PTIK study program FKIP UBH Padang City, and (3) learning motivation and attitude of learning together to the results of learning students in the course Digital Simulation study program PTIK FKIP UBH Padang City. This research is quantitative research with correlational type. The research population was 39 students. The sampling technique uses the Total Samplingtechnique, which means that the sample has the same number as the population. Data on learning motivation and learning attitudes were obtained through questionnaires using the Likertscale, while data on student learning outcomes in Digital Simulation courses were obtained from the final score of the even semester of FY 2019/2020. The data in the analysis uses statistical methods with the help of SPSS software version 17. The results of the data analysis showed that (1) there was a positive and significant relationship of learning motivation to student learning outcomes with a correlation coefficient of 0.531 , thus contributing $28.20 \%$. (2) Then, there is a positive and significant relationship between the attitude of learning towards student learning outcomes with a correlation coefficient of 0.559 , thus contributing $31.25 \%$. (3) Furthermore, there is a positive and significant relationship between learning motivation and learning attitudes together with student learning outcomes with a correlation coefficient of 0.657 thus contributing $43.16 \%$. This proves that learning motivation and learning attitudes contribute strongly in improving student learning outcomes in the Digital Simulation course of PTIK FKIP UBH study program in Padang City.
\end{abstract}

Keywords: learning motivation, learning attitude, student learning outcomes 



\section{INTRODUCTION}

According to the Great Dictionary of Indonesian Language (KBBI) states that education is the process of changing the attitudes and behaviors of a person or group of people in an effort to mature people through teaching and training efforts. Education is the process of making a person as himself and growing in line with his/her ability, ability, and conscience asa whole. Educators are not intended to print the character and abilities of learners just like their teachers,but proses education is directed at the proper functioning of all potential learners in a humane way so that they become themselves who have superior abilities and personalities (Mulyasana, 2011:2).

Furthermore, Dedi Mulyasana also argues that education is essentially a process of liberation of learners from ignorance, incompetence, helplessness, untruth, dishonesty and from bad heart, morality, and faith. Ali ibn Abi Talib r.a. reminded parents and or educators to teach children (learners) so that they are taught with knowledge so that they can live in a different era to the time when they studied.

From some of these views, it can be concluded that education is a learning process for students in order to obtain useful abilities and morals for students later. Therefore, a good education is an education that does not make an individual feel unfamiliar with himself. However, education must make the individual better acquainted with and understand about himself or herself.

Education has an important role for the development of learners. In addition to being an effort in transferring positive sciences, education is also a tool in empowering the potential of students. The formally obtained knowledge will result in each individual having a mindset, behavior and morals in accordance with the education obtained.

Based on some expert views, Mulyasana (2011:4) concluded several things about education, namely:

a. Education is related to the power in the process of the formation of mind and physical ethics to the level ofperfection.

b. Education is related to the process of emotional and humanitarian intellectual maturation conductedcontinuously.

c. Education is related to conscious efforts made through the teaching and training guidanceprocess.

d. Education is related to the efforts of influence and assistance to children so that they are capable in carrying out their lifeduties.

e. Education is related to the process of helping the development of self-quality towards the level of perfection.

f. Education is related to processes that influence the behavior habits, thoughts, and feelings of learners.

According to article 1 of the National Education System Law No. 20 Tahun 2003, national education serves to develop the ability and form the character and civilization of a dignified nation in order to educate the life of the nation, aiming to develop the potential 
of learners to become human beings who believe and fear God Almighty, have a healthy noble character with independent creative knowledge, and become a democratic and responsible citizen.

In the process education requires human resources that are able to transfer and guide the successors of the nation. Human resources referred to in the educational process one of them is students. Students are a term for someone who is studying or undergoing higher education in a college such as a high school, an academy, and the most common is a university. Based on this understanding, the process to produce qualified students is carried out in higher education. Higher education is the final focus of all levels of education and as a vehicle for the formation of scholars who have noble ethics, carry out cultural values, advance life and form satria pinandita (Harsono, 2008: 22).

In article 34 paragraph 2 of Government Regulation No. 2 of 1990, explains that the objectives of higher education are as follows:

a. Preparing students to become members of the community who have academic and or professional skills that can apply, develop or create knowledge, technology and or art.

b. Develop and disseminate science, technology and or the arts and strive to use them to improve living standards and enrich national culture.

Bung Hatta University is one of the private higher education in Padang city. The university, which was established on April 20, 1981, has seven faculties (24 courses), one master's program (6 courses), and one vocational program. Bung Hatta University continues to strive to improve the quality and quantity of its education in order to provide benefits for the welfare of the community both in the form of educational programs and in its learning curriculum.

Informatics and Computer Engineering Education (PTIK) is one of the study programs at the Faculty of Teacher Training and Education (FKIP) at Bung Hatta University (UBH). FKIP UBH aims to produce graduates who excel and dignified in the field of education who are able to compete in the era of globalization. Therefore, as one of the study programs in FKIP, PTIK always strives to improve the quality and quantity of its students. Benchmarks in seeing the quality of students one of them is through the results of learning. The results of the study can be seen from the value of lecturer evaluation of student performance in each course, both in the form of student attendance in the classroom, assignments, Midterm Exams (UTS), Final Semester Exams (UAS), and other learning activities.

High learning outcomes can be said that the student does the learning process well. Similarly, students with low learning outcomes, it is seen that the student is not good at the learning process and lectures.

Based on the data obtained in the Digital Simulation courses of informatics and computer engineering education program FKIP UBH, the following results were obtained. 
Table 1. Recapitulation of Student Value Data in Digital Simulation Courses of Informatics and Computer Engineering Education Program FKIP UBH

\begin{tabular}{|c|c|c|c|c|c|c|}
\hline \multirow{2}{*}{ Grade } & \multicolumn{2}{|c|}{$\begin{array}{c}\text { Academic Year } \\
2016 / 2017\end{array}$} & \multicolumn{2}{c|}{$\begin{array}{c}\text { Academic Year } \\
2017 / 2018\end{array}$} & \multicolumn{2}{c|}{$\begin{array}{c}\text { Academic Year } \\
2018 / 2019\end{array}$} \\
\cline { 2 - 7 } & $\begin{array}{c}\text { Number of } \\
\text { students }\end{array}$ & Percentage & $\begin{array}{c}\text { Number of } \\
\text { students }\end{array}$ & Percentage & $\begin{array}{c}\text { Number of } \\
\text { students }\end{array}$ & Percentage \\
\hline \hline A & 2 & $20 \%$ & 4 & $17 \%$ & 4 & $15 \%$ \\
\hline A- & 1 & $10 \%$ & 3 & $13 \%$ & 2 & $8 \%$ \\
\hline B+ & 0 & $0 \%$ & 2 & $8 \%$ & 3 & $12 \%$ \\
\hline B & 2 & $20 \%$ & 3 & $13 \%$ & 3 & $12 \%$ \\
\hline B- & 2 & $20 \%$ & 0 & $0 \%$ & 2 & $8 \%$ \\
\hline C+ & 1 & $10 \%$ & 1 & $4 \%$ & 3 & $12 \%$ \\
\hline C & 0 & $0 \%$ & 4 & $17 \%$ & 4 & $15 \%$ \\
\hline D & 0 & $0 \%$ & 4 & $17 \%$ & 2 & $8 \%$ \\
\hline And & 2 & $20 \%$ & 3 & $13 \%$ & 3 & $12 \%$ \\
\hline
\end{tabular}

Source: Data Lecturer Digital Simulation Course PTIK FKIP UBH

Grades with values below or equal to 70 starting at B-, C+, C, D, and E. From the table above, it can be known that the number of students who obtained a score of $\leq 70$ in the Academic Year 2016/2017 is as much as 5 students or equal to $50 \%$. Then in the Academic Year 2017/2018 students who obtained a score of $\leq 70$ as many as 12 students or equal to $50 \%$. In the Academic Year 2018/2019 students with a score of $\leq 70$ amounted to 14 students or equal to $54 \%$. This includes a considerable percentage, as up to $50 \%$ of students have a score below 70 .

There are several factors that can affect students' learning outcomes. Based on observations and interviews with lecturers who are masters of the course, there are several problems found. The problem found is the low activeness of students in following the learning process. When the lecturer asked for a response about the learning materials that have been presented, only 1 or 2 students gave a response. While other students tend to be silent without responding.

Then when the lecturer presented the material, some students did other activities and did not pay attention to the exposure given. Students seem to lack focus on giving their attention to learning materials. This makes students unable to answer questions given by lecturers.

In doing the task, many students who fill the discussion in their duties are more or less the same. The lack of independence in making assignments makes some students prefer to copy paste or duplicate the task of their friends rather than trying to make their 
own. Basically this shows that students lack motivation or motivation in learning so that it can affect their learning outcomes.

Students who have high learning motivation will try to fulfill all their learning activities as best as possible. Motivated students will learn the next learning material in order to better understand when the lecturer explains and can ask when something is poorly understood. Students with high learning motivation will try to find everything related to the learning material. Learning motivation is a psychological factor that is nonintellectual. His distinctive role is in the growth of passion, pleasure, and passion for learning (Sardiman, 2012:75).

The low motivation of learning can be seen from the low learning outcomes obtained by students. So it can be concluded that the motivation of learning has a relationship that is directly proportional to the results of learning. According to Hamalik (2012:179) that motivation is very important because a motivated group will be more successful than a group that does not have motivation (learning is less or does not work). Students who have high learning motivation will certainly have passion, enthusiasm, perseverance, and enterprising in learning. Students who are highly motivated will also not be easily tempted by things that are not important outside of learning activities. High learning motivation will make the learning results obtained will be more optimal.

Another problem that arises in the form of student attitude towards all activities in the learning process. Among these attitudes can be seen when collecting tasks. There are still students who are late in collecting assignments and are not excited when given assignments. Students complained and seemed unhappy because the assignments were given too much. Students consider that the task given by the lecturer is relatively difficult, so students are easily discouraged and reluctant to try to do it.

During class hours, students tend to be uneasy so often in and out of class. Students seem to be indifferent so impressed to consider the lessons given are not so important and necessary. Attendance also gives input to the assessment and evaluation of lecturers. despite knowing this, there are still students who often do not attend the class. Learning attitude certainly affects the results of learning.

According to Walgito (1987:110), attitude is a state in man that moves to act, accompanying man with certain feelings in response to objects formed on the basis of experiences. Based on this opinion that the attitude is said to have an effect on the noan. With a good learning attitude, the action in the learning process will be good. Students who have a positive learning attitude will give good actions in the form of attention, be diligent, and happy at all activities in learning. So that the students will get satisfactory learning results.

Student learning outcomes in digital simulation courses PTIK study program in the last three academic years can be said to have not been optimal. Judging from the interview results that several factors that affect student learning outcomes are learning motivation and learning attitude. Therefore, it can be concluded that the motivation of learning and 
attitude of learning can contibute on the learning outcomes of students of informatics and computer engineering education program FKIP UBH.

PTIK which is an educational program in the field of vocational, it is expected that students have skills or abilities in the field of IT and computers. As a study program at FKIP at UBH, Informatics and Computer Engineering Education is expected to produce graduates who fit their profile, namely:

a. Computer Science educators are people who educate the field of computers.

b. Research Assistant is a person who helps collect, process, analyze, and present data conducted systematically and objectively to solve a problem or test a hypothesis to develop general principles.

c. Entrepreneur in the field of computer science is a person who is able to be entrepreneurial, either making learning products or the field of learning services.

In order for the learning outcomes to be satisfactory, students must get good grades in each course. Courses in computer science group is a course that must be mastered by students, because the courses in this group are useful for skills or abilities that will be used by graduates in the job. Therefore, everything is tried by students and lecturers in order to improve learning outcomes. One of them is by improving motivation and learning attitude.

Cronbach (Surya, 1979:28) States, "Learning may be defined as the process by which a relatively enduring change in Behaviour occurs as a result of exprience orpractice". The statement asserts that learning indicators are determined by changes in behavior that are permanent as a result of experience or exercise. Regarding this type of behavior change in the learning process, Gagne and Briggs (1988:105), stated that the act of learning results in changes in the form of behavior in aspects: 1 ) the ability to distinguish; 2) concrete concept; 3) defined concept, notary code of conduct; 4) value; 5) high-level values/rules; 6) cognitive strategy; 7) verbal information; 8) attitude; and 9) motor skills. Bloom (Rusmono, 2014:8) also mentioned that the results of learning are behavioral changes that cover three areas, namely the cognitive, affective, and psychomotor spheres.

Broadly speaking, the factors that affect individual learning can be divided into two parts (Sobur, 2013:244):

a. Endogenous factors or also called internal factors, i.e. all factors that are in the individual.

b. Exogenous factors or also called external factors are all factors that are outside the individual.

Internal factors include: characteristics, learning attitude, motivation, concentration, processing materials, digging results, confidence and habits. While external factors are family factors, school factors, and other environmental factors.

Learning outcomes are all things that students get and have in this case are students, either in the form of knowledge or ability after he or she through the learning experience. The results of the study can be seen from the test scores given. According to 
Dimyati and Mudjiono (2006:4) that, "Learning outcomes are results achieved in the form of numbers or scores after being given a test of learning results at the end of each learning". The value obtained becomes a reference to see the mastery of learners in receiving lesson materials.

Learning motivation is a psychic driving force from within a person to be able to do learning activities and add skills and experience (Yamin, 2007: 219). Then according to Uno (2008:23) in fact the motivation of learning is the presence of internal and external motivation in learners who are learning to make changes in behavior. In the field of education, motivation is certainly oriented towards the achievement of psychological conditions that encourage a person to be passionate in his learning (Thoifuri, 2007:96).

Based on this understanding that learning motivation is a psychological driving force in the individual in the form of internal and external motivation to learn. Students must have high learning motivation in order for their learning activities to run as they should. So that it can add useful skills and knowledge in life. As well as being able to change behavior based on actual purpose.

Uno (2013:23) classifies the following learning motivation indicators:

a. Desire and desire succeed.

b. There is encouragement and need in learning.

c. There are hopes and ideals of the future.

d. There is an appreciation in learning.

e. There are interesting activities in learning.

f. There is a conducive learning environment, thus allowing a student to learn well.

Then Keller (1987:289) presented 4 indicators in learning that affect the motivation of learners, namely arcs model. ARCS is an acronym of attitude form namely attention, relevance, confidence and satisfaction.

Attitude is a response to conditioned social stimulus (Azwar, 2000:5). According to Scond and Backman, defining attitudes as a certain regularity in terms of feelings (affection), thinking (cognition), and predisposition of one's actions (konasi) to an aspect of the surrounding environment (Azwar 2000:5). Based on this opinion, that attitude can be concluded as a response of feelings, thoughts, and actions to everything in the surrounding environment.

Social psychologists found three main sources of attitude (Calhoun \& Acocella, 1990:289). First, personal experience. Attitude can be the result of a pleasant or painful experience with the object of attitude. The second possible source of attitude in this regard is the transfer of painful feelings. Displacement is to subconsciously divert painful feelings (especially hostility) away from the actual object on another, safer object. The third source of attitude is social influence and will probably be the main source.

The attitude of learning is the response of students who in this case are students in the form of feelings, thoughts, and actions on all aspects related to learning. Whether or not the learning process is done by the learner depends on the attitude of the learner. 
A positive attitude towards learning will have a positive impact as well. Similarly, negative attitudes will have an impact on not absorbing the results of learning to the maximum. Therefore, educators need to encourage a positive learning attitude from students so that student learning outcomes are expected to be more optimal.

According to Singer (1987) that the attitude of learning is not only the attitude shown to educators, but also to the goals to be achieved, subject matter, assignments, and others. Furthermore, Sabri also revealed that changes in attitude can be observed in the learning process, goals to be achieved, firmness, and consistency towards something.

Attitude assessment is an assessment that is done to know the attitude of students to courses, learning conditions, educators, and so on. Thus, to know the results of the learning process and internalization of certain values, it is necessary to conduct an attitude assessment (Widoyoko, 2004:39).

\section{METHOD}

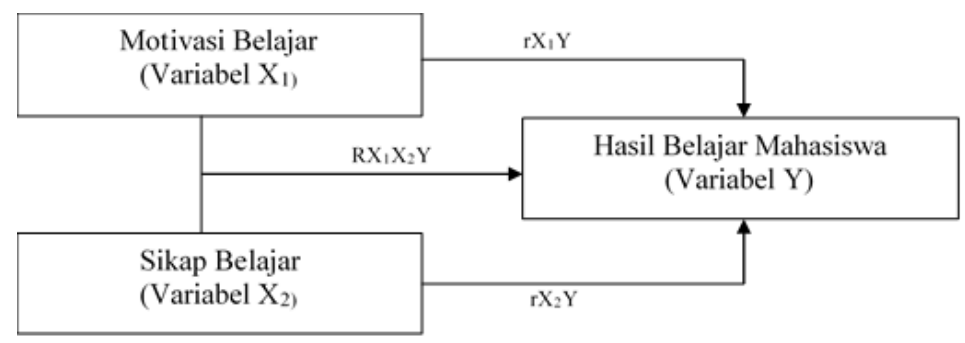

Figure 1. Conceptual Framework

Based on the problems that have been raised, this research includes quantitative research, because the data of the research results are measured and converted in the form of numbers and analyzed with statistical techniques (Sugiyono, 2016). Then seen from the moment of occurrence, this research is descriptive. According to Arikunto (2006:10), research conducted by explaining or describing variables past and present (happening), is descriptive research. In descriptive methods, data is collected, systematically compiled, faktua and meticulously, but not explained the relationship between variables, not conducting hypothesis or prediction tests.

Then based on its type, this study is a correlational study. In the correlational method, the relationship between variables is studied and explained. Sukmadinata (2010: 56) stated that correlational research is intended to determine the relationship of a variable with other variables. The relationship between one variable and another is expressed by the magnitude of the correlation coefficient and significance.

In this study, the population was students in the Digital Simulation course of PTIK FKIP UBH Study program in Padang Academic Year 2019/2020 which amounted to 39 students. The sampling technique in this study is Total Sampling. According to Arikunto (2006:120) total sampling is the same sampling as the existing population. 
The research instrument used consists of several statement items using the Likert scale with five alternative answers. Before the instrument is used in the research, the instrument is first conducted. Analysis of instrument test data using two stages, namely validity test and reliability test.

Then, the research questionnaire was distributed to sample respondents. The research data was conducted descriptive analysis test and prerequisite analysis test consisting of normalization test, linearity test, and multicollinearity test. Then the research data conducted regression tests and correlation tests and the latter determine the coefficient of contribution.

\section{RESULTS AND DISCUSSION}

This study aims to reveal a meaningful relationship between learning motivation and learning attitude towards learning outcomes in digital simulation courses of Informatics Engineering education program and Computer FKIP UBH in Padang city. The discussion of the results of the study here refers to data obtained through learning motivation questionnaires, study attitude questionnaires, student final grades, as well as interviews and observations.

Based on calculations using the SPSS statistics program, in the study motivation questionnaire there are 3 invalid items and 43 valid items. The learning attitude questionnaire has 5 invalid items and 40 valid items. The results of reliability test analysis showed the value of Cronbach Alpha learning motivation instrument ( $\left.\mathrm{X}_{1}\right)$ i.e. $\mathrm{r}_{11}=0.989$ and learning attitude instrument $\left(\mathrm{X}_{2}\right)$ obtained $\mathrm{r}_{11}=0.977$. So it can be concluded that the instrument of learning motivation $\left(\mathrm{X}_{1}\right)$ and learning attitude $\left(\mathrm{X}_{2}\right)$ is a valid and reliable instrument with a very strong level of relationship.

Then, the research questionnaire was distributed to sample respondents. The results of descriptive analysis obtained the degree of achievement of variable $Y$ in this study was categorized as sufficient with a value of $64.82 \%$. Variable achievement degrees $\mathrm{X} 1$ and $\mathrm{X} 2$ are said to be good with values of $84.80 \%$ and $84.98 \%$.

\section{Test Analysis Requirements}

Before conducting data analysis, there are several requirements that must be met. From the results of normality test using Kolmogorov-Smirnov (K-S Test) Test obtained that variable data X1 and X2 and Y are at the level of significance $>\alpha 0.05$. So it can be concluded, the data in this study is on normal distribution. In the following table can be seen the results of recapitulation test normality data.

Furthermore, $\mathrm{X}_{1}$ linearity test against $\mathrm{Y}$ was obtained results in linearity lane significance worth 0.013 and on Dev lane. From Linearity the significance value is 0.935 . In linearity test $\mathrm{X}_{2}$ to $\mathrm{Y}$, linearity of significance is 0.001 and dev lane is generated. From Linearity the significance value is 0.298 . It meets the requirement of linearity $>0.05$, so it can be inferred linear data. 
In the multicollinearity test the variable Tolerance values $X_{1}$ and $X_{2}$ were 0.856 , then $0.856>0.10$ and the VIF value was 1.168 , then $1.168<10$. Dapat concluded that there is no multicolinearity between independent variables (free).

\section{Hypothesis Testing}

\section{1) Contribution of Learning Motivation to Learning Outcomes}

Based on the results of the first hypothesis test that reads "There is a meaningful relationship between the motivation of learning to the learning outcomes of students in the Digital Simulation courses of Informatics Engineering Education and Computer FKIP UBH" obtained the results of the regression match test with the equation with the value of $Y^{\prime}=-28,182+0,528 X \mathrm{t}$ count $\mathrm{t}$ table $(3,816>-2,026)$ and significance $<0.05(0.000<0.05)$. These results give an idea that the hypothesis presented in this study is accepted.

Then the result from the correlation test of Learning Motivation $\left(\mathrm{X}_{1}\right)$ to Student Learning Outcomes (Y) obtained a correlation coefficient value of $r \mathrm{X}_{1} \mathrm{Y}=0.531$. It can be concluded that there is a significant relationship between learning motivation to the learning outcomes of students of Digital Simulation courses of PTIK FKIP UBH study program. The coefficient of contribution of learning motivation to the learning outcomes of students of Digital Simulation courses of PTIK FKIP UBH study program is $28.20 \%$. It can be interpreted that Motivation to Learn $\left(\mathrm{X}_{1}\right)$ contributes $28.20 \%$ to student learning outcomes (Y),while the remaining71.80\% is influenced by other variables. In this study, it was not discussed about these other variables.

Based on the value and coefficient of correlation obtained, it can be concluded that learning motivation correlates with student learning outcomes in digital simulation courses of Informatics Engineering and Computer Education study program FKIP UBH. This leads to better learning motivation, the better the student's learning outcomes. On the contrary, the less motivation to learn, the decrease in student learning outcomes. According to Uno (2008:23) in fact the motivation of learning is the presence of internal and external motivations in learners who are learning to make changes in behavior.

Some things that can be done to increase the motivation of learning in digital simulation courses of Informatics And Computer Engineering Education study program FKIP UBH are as follows:

a) Courses can improve the quality and learning facilities. With good facilities, students will be motivated to follow the learning process.

b) Lecturers can provide a method of delivering materials that are integrated so that students do not feel bored.

c) Lecturers can also provide an understanding that this given material is indispensable later in life. 
d) Lecturers can then provide relevant feedback to students during the learning process so as to increase student morale.

e) Study programs and lecturers are also expected to provide a platform to accommodate the weaknesses of students in understanding the material, then provide explanations that can develop student understanding.

f) Then give an award in the form of praise or value for students who are able to give feedback in learning.

\section{2) Contribution of Learning Attitude to Learning Outcomes}

Based on the results of the second hypothesis test that reads "There is a meaningful relationship between the attitude of learning to the learning outcomes of students in the digital simulation courses of Informatics Engineering Education and Computer FKIP UBH" obtained the results of regression match test with the equation with the value of $Y^{\prime}=-42,564+0,853 X$ t count $t$ table $(4,104>-2,026)$ and significance $<0.05(0.000<0.05)$. These results give an idea that the hypothesis presented in this study is accepted.

Furthermore, the results of the correlation test of Learning Attitudes $\left(\mathrm{X}_{2}\right)$ to Student Learning Outcomes (Y) obtained a correlation coefficient value of $\mathrm{r} \mathrm{X} 2 \mathrm{Y}=$ 0.559. It can be concluded that there is a significant relationship between learning attitudes towards the learning outcomes of students of Digital Simulation courses of PTIK FKIP UBH study program. The coefficient of contribution of learning attitude to the learning outcomes of students of Digital Simulation courses of PTIK FKIP UBH study program is $31.25 \%$. It can be interpreted that the attitude of learning contributes $31.25 \%$ to student learning outcomes, while the remaining $68.75 \%$ is influenced by other variables. In this study, it was not discussed about these other variables.

Based on the value and coefficient of correlation obtained, it can be concluded that the learning attitude correlates with the learning outcomes of students in the Digital Simulation courses of informatics and computer engineering education program FKIP UBH. This causes the better the attitude of learning, the better the student's learning outcomes. On the contrary, the less good the attitude of learning, the decrease in student learning outcomes.

According to Sabri (2002) that the attitude of learning is a feeling of pleasure or displeasure, a feeling of agree or disapproval, a feeling of likeness or dislike towards educators or lecturers, goals, materials and tasks and others. The attitude of learning is the response of students who in this case are students in the form of feelings, thoughts, and actions on all aspects related to learning. Whether or not the learning process is done by the learner depends on the attitude of the learner. A positive attitude towards learning will have a positive impact as well. Similarly, negative attitudes will have an impact on not absorbing the results of learning to the maximum. 
Therefore, educators need to encourage a positive learning attitude from students so that student learning outcomes are expected to be more optimal.

In improving the attitude of learning in digital simulation courses of Informatics and Computer Engineering Education study program FKIP UBH, lecturers and educators can do several things, namely:

a) By fostering a sense of pleasure, agree, and student likeness to lecturers, learning materials, assignments given, and class conditions. Feeling happy, agreeing, and liking something can improve the atmosphere of feeling so that it can accept everything given. This can be improved by making the educator in this case a lecturer as a pleasant person for students.

b) Can provide relevant value to the efforts and assignments of students so that students can receive it.

c) A positive attitude can also be improved from supportive class conditions. Good class conditions can be created by improving facilities such as by providing infokus, Air Conditioner, and others.

d) The suitability of the task with the material provided can also improve the student's likeness in completing the given task.

\section{3) Contribution of Learning Motivation And Learning Attitude to Learning Outcomes}

From the results of the third hypothesis test that reads "There is a meaningful relationship between learning motivation and learning attitude towards learning outcomes in digital simulation courses of Informatics Engineering education program and Computer FKIP UBH" obtained the results of regression match test with the equation with the $Y^{\prime}=-78,323+0,371 X_{1}+0,637 X_{2}$ value of $\mathrm{F}$ count $>\mathrm{F}$ table $(13,679>3,259)$ and significance $<0.05(0,000<0.05)$. These results give an idea that the hypothesis presented in this study is accepted.

Then the value of the correlation test of Learning Motivation ( $\left.\mathrm{X}_{1}\right)$ and Learning Attitude $\left(\mathrm{X}_{2}\right)$ to Student Learning Outcomes $(\mathrm{Y})$ obtained $\mathrm{R} \mathrm{X}_{12} \mathrm{Y}=0.657$. It can be concluded that there is a strong relationship between learning motivation and learning attitude towards the learning outcomes of students of Digital Simulation courses of PTIK FKIP UBH study program. The coefficient of contribution of learning motivation and learning attitude to the learning outcomes of students of Digital Simulation courses of PTIK FKIP UBH study program amounted to $43.16 \%$.

Based on the value and coefficient of correlation obtained, it can be concluded that the motivation of learning and learning attitudes are jointly correlated with the learning outcomes of students in the Digital Simulation courses of informatics and computer engineering education program FKIP UBH. This leads to better learning motivation and learning attitude, the better the student's learning outcomes. On the 
contrary, the less good the attitude of learning, the decrease in student learning outcomes.

Based on the value and coefficient of correlation obtained, it can be concluded that the motivation of learning and learning attitudes are jointly correlated with the learning outcomes of students in the Digital Simulation courses of informatics and computer engineering education program FKIP UBH. This leads to better learning motivation and learning attitude, the better the student's learning outcomes. On the contrary, the less good the attitude of learning, the decrease in student learning outcomes.

\section{CONCLUSION}

Therefore, from the findings above, it can be seen that learning motivation and learning attitudes influence and contribute strongly to student learning outcomes. This is in line with the opinion of Aunurrahman that internal factors that affect the learning process include motivation and learning attitude. For more details of the magnitude of correlation of each variable.

\section{Author Biodata}

Mulya Melda, born August 26, 1993 in Geringging River, West Sumatra Province. Bachelor of Education in Informatics and Computer Engineering Education, Faculty of Teacher Training and Education, Bung Hatta University in 2011. Currently a Postgraduate master's program in technology and vocational education program, Faculty of Engineering, State University of Padang.

Dr. Hasan Maksum, MT., born August 17, 1966 in Trt. Umbrella of Aceh Province, he is a lecturer and Chairman of master's program in Technology and Vocational Education, Faculty of Engineering, State University of Padang.

Dr. Eko Indrawan, S.T., M.Pd., born January 14, 1980 in Kijang Indragiri Hilir Island, Riau Province, he is a lecturer in mechanical engineering department, Faculty of Engineering, State University of Padang.

Dr. Dori Yuvenda, S.Pd., M.T., born November 1, 1988 in Bukittinggi, West Sumatra Province, he is a lecturer in the department of Automotive Engineering, Faculty of Engineering, State University of Padang.

\section{REFERENCES}

Arikunto, S. (2006). Metode Penelitian Kualitatif. Jakarta: Bumi Aksara. Aunurrahman. (2009). Belajar dan Pembelajaran. Bandung: Alfabeta. Azwar. (2000). Sikap Manusia, Teori dan Pengukurannya. Yogyakarta: Pustaka Pelajar. Badan Pengembangan dan Pembinaan Bahasa. (2016). Kamus Besar Bahasa Indonesia (KBBI). Kementerian Pendidikan dan Kebudayaan Republik Indonesia. (Online) 
(https://kbbi.kemdikbud.go.id/entri/pendidikan, diakses pada tanggal 01 Desember 2020).

Calhoun, James F., and Joan Ross Acocella. (1990). Psychology of Adjustment and Human Relationsship Third Edition. New York: McGraw-Hill Publishing Company.

Depdiknas. (2003). Undang-undang RI No.20 tahun 2003. Tentang sistem pendidikan nasional.

Dimyati dan Mudjiono. (2006). Belajar dan Pembelajaran. Jakarta: Rineka Cipta.

Gagne, R.M., Briggs, L.J \& Wager, W.W. 1988. Principles of Instruction Design, 3rd edition.

New York: Saunders College Publishing.

Harsono. (2008). Pengelolaan Perguruan Tinggi. Yogyakarta: Pustaka Pelajar.

M. Keller, John. (1987). "Development and Use of The ARCS Model of Instructional Design". Jurnal of Instructional Development.

Mulyasana, Dedy. (2011). Pendidikan Bermutu dan Berdaya Saing. Bandung: PT Remaja Rosdakarya.

Rusmono. (2014). Strategi Pembelajaran dengan Problem Based Learning. Bogor: Ghaliah Indonesia.

Sabri, Alisuf. (2002). Psikologi Pendidikan. Jakarta: CV Pedoman Ilmu Jaya.

Sardiman AM. (2012). Interaksi \& Motivasi Belajar Mengajar. Jakarta: PT. Rajagrafindo Persada.

Singer, Kurt. (1987). Membina Hasrat Belajar di Sekolah (Terjemahan). Bandung: CV Remadja Karya.

Sobur, Alex. (2013). Psikologi Umum dalam Lintasan Sejarah. Bandung: CV. Pustaka Setia. Sugiyono. (2016). Metode Penelitian Kuantitatif, Kualitatif dan R\&D. Bandung: PT Alfabet.

Sukmadinata, Nana Syaodih. (2010). Metode Penelitian Pendidikan. Bandung: PT Remaja Rosdakarya.

Surya, Moh. (1979). Psikologi Pendidikan. Bandung: Publikasi Jurusan PPB FIP IKIP Bandung.

Thoifuri. (2007). Menjadi Guru Inisiator. Semarang: Rasail.

Uno, H. (2008). Teori Motivasi dan Pengukurannya. Jakarta: Bumi Aksara. H., dkk. (2013). Assessment Pembelajaran. Jakarta: Bumi Aksara.

Walgito, Bimo. (1987). Psikologi Sosial. Yogyakarta: Yayasan Penerbit Fakultas UGM.

Widoyoko, Eko Putro. (2004). Penilaian Hasil Pembelajaran di Sekolah. Yogyakarta: Pustaka Pelajar.

Yamin, Martinis. (2007). Profesionalisasi Guru \& Implementasi KTSP. Jakarta: Gaung Persada Press. 